University of Michigan Law School

University of Michigan Law School Scholarship Repository

1915

\title{
Breach of Landlord's Covenant as Defense to Action for Rent
}

\author{
Ralph W. Aigler \\ University of Michigan Law School
}

Available at: https://repository.law.umich.edu/articles/1601

Follow this and additional works at: https://repository.law.umich.edu/articles

Part of the Housing Law Commons

\section{Recommended Citation}

Aigler, Ralph W. "Breach of Landlord's Covenant as Defense to Action for Rent." Mich. L. Rev. 13 (1915): 317-8.

This Article is brought to you for free and open access by the Faculty Scholarship at University of Michigan Law School Scholarship Repository. It has been accepted for inclusion in Articles by an authorized administrator of University of Michigan Law School Scholarship Repository. For more information, please contact mlaw.repository@umich.edu. 


\section{Michigan LAW REVIEW}

PUBIISBED MONTELY DURING THE ACADENIC YEAR, EXCIUSIVE OF OCTOBER, BY THE LAW FACULTY OF THE UNIVERSITY OF MICHICAN

SUBSCRIPTION PRICE \$2.80 PER YEAR.

3E CENTS PER NUMBER

EvaNs Hor,BROOK; Editor

ADVISORY BOARD.

HENRY M. BATES

VICTOR H. LANP

HORACE I. WIIGUS

Editorial Assistants, appointed by the Faculty from the Class of 1915:

WILL F. BLACK, of Ohio.

HeNRy C. Bogle, of Michigan.

Marcy K. Brown, Jr, of Missouri.

Jorn G. Cedergren, of Minnesota.

Charles Davidson, of Montana.

AREND V. DuBEe, of Wisconsin.

LEVI M. HALl, of Minnesota.

Victor H. HAsspton, of Michigan.

Holtis HARSH SAAN, of Michigan.

BuEII MCCASE, of Iowa.
Lestie C. MCClecrand, of Michigan.

WALTER I. MCKenzIE, of Michigan.

KARL J. MOHR, Of Illinois.

Roswere B. O'HARrA, of Illinois.

ALLEN M. REed, of Illinois.

WiLr R. Roberis, of Michigan.

HENRY Rottschasfer, of Michigan.

CARI, G. SchoEFFEL, of Illinois.

J. G. TuCKER, JR, of Michigan.

\section{NOTE AND COMMENT.}

BREACH of LANDLORD'S COVENANT AS DEFENSE to ACTION FOR REN'-It is undoubtedly well settled that if the agreement to pay rent is dependent upon the performance by the landlord of some undertaking on his part, the failure by the landlord so to perform is a good defense to an action for the rent. It is equally well settled that if the agreements are independent such failure by the landlord is no defense. The difficulty arises in determining whether the agreements are dependent or independent. That question is one of construction, and it cannot be expected that all the cases may be satisfactorily reconciled. Two very late cases involving this question are of interest. In Stewart v. Childs Co., (N. J.) 92 Atl. 392, decided Nov. I6, 1914, the court decided that a tenant's obligation to pay rent was not dependent upon the performance by the landlord of a guaranty that the basement should be kept waterproof, although it appeared that the water in the cellar had made the premises impossible for the carrying on of the tenant's business for which the premises had been leased, and the tenant as a result moved out. The court treated the case as depending upon constructive eviction. On the other hand in University Club of Chicago v. Deakin, (I11.) 106 N. E. 790, decided Oct. I6, 1914, the court concluded that the rent obligation ceased upon the landlord's breach of a covenant that it would not "rent any other store in 
said University Club building to any tenant making a specialty of the sale of Japanese or Chinese goods or pearls." The tenant had moved out. The IIIinois court puts the case upon the basis of a bilateral contract with dependent promises. No reference is made in the opinion to Chicago Legal News Co. v. Brozene, I03 III. 3I7, wherein it was held that the rent obligation had not ceased upon the breach by the landlord of an agreement not to lease adjoining premises for saloon purposes. In the last mentioned case it did not appear that the tenant had moved out, but no reliance seems to have been put upon that fact. Cases of the type under consideration, it seems, should not be made to turn upon the giving up of possession, for properly they are not cases of eviction, but of general contract law. If the conclusion from the terms of the lease be that the parties intended the agreements to be dependent and there has been a breach of the landlord's undertaking, the tenant should not be held liable whether he has remained in possession or movedi out. Remaining in possession despite the breach by the landlord may be important as evidence to show a waiver, but certainly it ought not to be conclusive on that point.

The Deakin case may also be open to the criticism that the landlord had not really broken its covenant. The premises were demised to Deakin to be used for a jewelry and art shop and for no other purpose. The lessor covenanted with reference to leasing other parts of the building as stated above. Another room in the building was leased to one Sandberg with a covenant on his part that the premises leased should not be used "for a collateral loan or pawnshop or make a specialty therein of the sale of pearls." Deakin claimed that Sandberg had made a specialty of selling pearls, that the common lessor had done nothing to stop him, and that for that reason Deakin had moved out. The lower court held that by incorporating the above stipulation in the lease to Sandberg the lessor had performed all the obligations imposed upon it by the lease to Deakin: The Supreme Court held that to be error, that there was an obligation imposed upon the lessor to stop the second lessee from making a specialty of selling pearls. The court refers to Lucenthe v. Davis, Ior Md. 526, 6I Atl. 622, where the rule adopted by the lower court was laid down and refuses to follow same. To the same effect as the case last cited is Ashby v. Wilson, (1900) I Ch. 66, where the court quoting from Kemp v. Bird, 5 Ch. D. 978 , said, "I know of no authority for saying that under such circumstances as these'-and for my purpose I think the circumstances here are sufficiently similar-'a landlord is a trustee for his tenant in the sense that he must, at the request of the lessee, enforce a covenant against another lessee." "

R. W. A. 